\title{
Andreas F Widmer for the Basel infection control team
}

\author{
AF Widmer ${ }^{*}$, Infection control team \\ From International Conference on Prevention \& Infection Control (ICPIC 2011) \\ Geneva, Switzerland. 29 June - 2 July 2011
}

\section{Introduction / objectives}

Hand hygiene belongs to the basic components of any infection control program. Compliance is still an important issue, but the hand hygiene technique has gathered little attention. Proper technique of hand hygiene significantly improves bacterial killing, but few studies addressed this issue.

\section{Methods}

The University of Basel hospitals is a 900 bed tertiary care center with 5 Intensive CUs and kidney and bone marrow transplant program. After introduction of the alcoholic hand rub in 1970, hand washing has been replaced with the alcoholic hand rub in $>90 \%$. Since 2007, health care workers and medical students are routinely trained to apply the proper technique.

\section{Results}

1'030 observations were made in different wards, emergency rooms, ICUs and transplant units. Overall compliance with all 6 steps was $13.4 \%$. The steps focusing on the fingertips and the thumb were frequently missed, namely $83-90 \%$ for nurses and $95-97 \%$ for physicians $(\mathrm{p}<0.05)$.

\section{Conclusion}

The compliance with hand hygiene technique requires more focus and training: the thumb and the fingertips are frequently not adequately in contact with alcohol. Several techniques have been proposed, but basic training should ensure that the fingertips and the thumb are not missed during the alcoholic rub-in.

Infectious disease and Hospital epidemiology, University of Basel, Basel, Switzerland

\section{Disclosure of interest}

A. Widmer Grant/Research support from Ecolab, Switzerland, Speaker's Bureau of 3m, Switzerland.

Published: 29 June 2011

doi:10.1186/1753-6561-5-S6-P123

Cite this article as: Widmer and : Andreas F Widmer for the Basel infection control team. BMC Proceedings 2011 5(Suppl 6):P123.

Submit your next manuscript to BioMed Central and take full advantage of:

- Convenient online submission

- Thorough peer review

- No space constraints or color figure charges

- Immediate publication on acceptance

- Inclusion in PubMed, CAS, Scopus and Google Scholar

- Research which is freely available for redistribution 